\title{
EXPLAINING UNION PARTICIPATION: THE EFFECTS OF UNION COMMITMENT AND DEMOGRAPHIC FACTORS
}

\author{
D BOLTON \\ J J BAGRAIM \\ jbagraim@commerce.uct.ac.za \\ L WITTEN \\ Y MOHAMED \\ V ZVOBGO \\ M KHAN \\ School of Management Studies \\ University of Cape Town
}

\begin{abstract}
This study examined the relationship between trade union commitment and union participation among blue-collar workers in South Africa. Survey questionnaires were completed by 93 participants (response rate $=62 \%$ ). Findings are consistent with previous research and showed that after controlling for demographic factors, $43 \%$ of the variance in participation can be explained by union commitment. In this study, Black participants displayed significantly higher levels of commitment and participation than their Coloured counterparts did.
\end{abstract}

Key words

Union participation, union commitment

Trade unions, as formally organised coalitions of employees (Bendix, 2004), encourage participation in collective activities as the primary means to achieve their goals (Metochi, 2002). A marked decline in trade union density has been observed in the United States (Clawson \& Clawson, 1999) and the United Kingdom (Smith \& Morton, 1993). In South Africa declines in trade union density, though less dramatic than those in the Unites States and Europe, are still significant (Theron, 2003).

Union participation refers to involvement in collective action (Metochi, 2002) and other union related activities (McShane, 1986) that are closely related to the effective functioning of the union (Sverke \& Kuruvilla, 1995). Union participation activities can been classified as either formal activities or informal activities (Fullagar \& Barling, 1989). Formal activities include involvement in elections, meeting attendance, voting, filing a grievance and serving as an officer (Fullagar, Gallagher, Gordon \& Clark, 1995); these are activities that are infrequent and scheduled. In contrast, informal activities include helping other members to file grievances, talking about the union with friends or family, and reading union-related publications (Fullagar et al., 1995); these are activities that are less formal but typically more frequent. These definitions are not universally accepted in the literature. Tetrick (1995) conceptualised informal activities as extra-role behaviours involvement beyond what is required, whereas Heshizer and Lund (1997) conceptualised informal activities as those rendering compliance with minimal role expectancies. McShane (1986) rejected the two-dimensional approach to understanding participation in the union and proposed a model with three dimensions, categorised by type of activity (meeting, voting and administrative) and not by nature of activity (formal and informal). These differences in the literature suggest that a clear, widely endorsed conceptualisation of union participation is still required.

Union participation should be distinguished from worker participation, the involvement of employees in the organisation's planning, decision making and operational processes (Bendix, 2000; Venter, 2003). In contrast to union participation, worker participation usually locates itself primarily in employer- employer conflict, the collective bargaining process and the tempering of managerial prerogative (Bendix, 2000). Worker participation goes beyond the ambit of collective bargaining as it is a style of management that recognises the right and needs of employees, individually or collectively, to meaningfully participate and contribute to the decision making and running of the organisation (Salamon, 1998; Venter 2003). Collective bargaining is the process by which employers and organised groups of employees usually trade unions, seek to reconcile their conflicting goals through mutual accommodation (Grogan, 2003). It is premised on the joint regulation of the employment relationship through cooperation, commonality, trust and compromise (Venter, 2003). Union participation in the process of collective bargaining is paramount in the South Africa labour relations context as it not merely a mechanism for reconciling conflicting interests in the employment relationship but plays a positive role in the building of harmonious employment relations (Venter, 2003).

Regardless of definitional complexities, the raison d' être of any union can only be fulfilled if its members are taking part in its formal activities (Fullagar et al., 1995). Hence, exploring what motivates participation is of significant value to labour leaders (Gallagher \& Clark, 1989)

\section{Predictors of union participation}

Recent research has considered two variables as possible predictors of union participation namely union commitment and demographic factors, with the former being widely accepted as the more significant antecedent (Fullagar, 1986; Fullagar, Gallagher, Clark \& Carroll, 2004; Gallagher \& Clark, 1989; Sverke \& Kuruvilla, 1995). Gordon, Philpot, Burt, Thompson and Spiller (1980) defined union commitment as the extent to which a member has a strong desire to retain union membership, is willing to put effort in the union, and believes in union objectives. Despite the existence of several alternate models of union commitment, with between one and five dimensions (Sverke \& Kuruvilla, 1995), Gordon et al.'s (1990) four-dimensional model of union commitment remains the most established and widely used model (Barling, Fullagar \& Kelloway, 1992). The four dimensions comprise: (a) Union loyalty, reflecting a sense of pride and an awareness of the benefits of union membership; (b) Responsibility to the union, reflecting a member's willingness to fulfill daily obligations to the union; (c) Willingness to work for the union, reflecting 
readiness to partake in activities beyond what is normally expected; (d) Belief in unionism: reflecting general support for the idea of trade unionism. Of the four dimensions, union loyalty is the most prominent and consistent characteristic of union commitment (Fullagar, 1986; Fullagar, McCoy \& Shull, 1992; Fullagar et al., 1995). It was also found to have a positive and significant direct relationship to participation (Gordon et al., 1980) in the South African context (Fullagar, 1986; Fullagar \& Barling, 1989).

Friedman and Harvey (1986) suggested a condensed twodimensional alternative to Gordon et al.'s (1980) model. Their model, based on the theory of reasoned action, proposes the following two dimensions of union commitment: (a) Union related attitudes and opinions, incorporating dimensions 1 and 4 of Gordon et al.'s (1980) model; and (b) Behavioural intentions, incorporating dimensions 2 and 3 of Gordon et al.'s (1980) model. Behavioural intentions were shown to mediate the relationship between union related attitudes and opinions, as well as actual participation.

Sverke and Kuruvilla (1995) discussed another two-dimensional model, the rationalistic approach. In this model union commitment comprises of: (a) A value, rationality-based dimension that reflects the extent to which members identify with, and internalise the values and goals of the union; and (b) An instrumental, rationality-based dimension that reflects an exchange relationship, whereby commitment is determined by the perceived benefits a member gleans as a result of unionization. Instrumental rationality-based commitment predicted a member's intent to remain a member of the union while value-rational commitment predicted a member's participation in union activities (Sverke \& Kuruvilla, 1995). It is interesting to note that value rationality-based commitment has been termed both affective commitment (Snape, Redman \& Chan, 2000) and normative commitment (Heshizer \& Lund, 1997), further evidencing the extent of the confusion in the union commitment literature.

Sverke and Kuruvilla (1995) proposed an integrated model that incorporates the two two-dimensional models described above. Union commitment is presented as two-dimensional (adopting the rationalistic approach), and the relationship between commitment and participation is presented with behavioural intentions as a mediator of the relationship (Friedman \& Harvey, 1986). In their meta-analysis Bamberger, Kluger and Suchard (1999) proposed a similar integrated model, but eliminated the mediating effect of behavioural intentions, and set union instrumentality and union related attitudes as direct antecedents of union commitment.

Much of the research on the relationship between union commitment and participation is cross-sectional in nature, which is useful for correlational inferences only. The few longitudinal studies that have been conducted (Fullagar et al., 2004; Gallagher \& Clark, 1989), which have more power in establishing a causal relationship between the two constructs, indicate that early union commitment is predictive of union participation 8 months later (Fullagar \& Barling, 1989), as well as 10 years later (Fullagar et al., 2004). This relationship was also shown to be unidirectional, in that participation did not predict commitment. This important finding informed the development of the research presented in this paper.

It should be noted that while union commitment is the most discussed antecedent of union participation, it is not the only one. Empirically evidenced antecedents of union participation include socialisation processes (Fullagar et al., 1992), union instrumentality, pro-union attitudes (Bamberger et al., 1999) alienation in the workplace (Fullagar, Barling \& Kelloway, 1992), industrial relations climate (Deery \& Iverson, 1998), union satisfaction (Johnson \& Johnson, 1997), leadership behaviour (Metochi, 2002) and the transformational leadership attributes of shop stewards (Kelloway \& Barling, 1993). Janse Van Rensberg and Roodt (2005) found that employees' perceptions of employment equity and black economic empowerment help explain union commitment in the South African context. Theoretical postulates regarding the motives that influence employees' decision to join a union vary across disciplines and ideologies (Gani, 1996). Marxists (Marx \& Engels, 1997) consider union membership in terms of employee dissatisfaction with the existing system and their political determination to oust the "oppressive order". Economists (Bain \& Price, 1983; Mason \& Bain,1993) tend to emphasise identify factors such as unemployment, governmental policies and the structure of industry. Rational choice theorists (Cooke et al., 1975; Deery \& Cieri, 1991) propose that rational employees join unions based on the perception that union benefits outweigh the cost of union membership. Sociologists highlight that an individual's social context, both inside and outside the workplace, may strongly influence them to join a union or not (Cooke, 1983).

The effect of demographic variables on union commitment and participation has been researched for some time, but research results are inconsistent and inconclusive (Heshizer \& Lund, 1997; Snape, Redman \& Chan, 2000). The three most significant demographic variables in the union commitment literature are gender, age and race: Men have been found to be significantly more likely to partake in union activities than females (Gordon et al., 1980; Metochi, 2002) but women have also been found to have stronger union loyalty than males (Gallagher \& Clark, 2001). Union members from their midtwenties to mid-forties have been found to be significantly more likely to partake in union activities (Metochi, 2002). Regarding race, Fullagar (1986) found that Black and White trade union members in South Africa had equivalent levels of union commitment on all but one dimension. He further found that White union members expressed greater responsibility to the union than their black counterparts did; a result he ascribed to the interaction between tenure and union responsibility, not race.

The strong indication is that union commitment is the primary motivator of union participation (Barling \& Fullagar, 1991). However, there still appears to be no consensus on the conceptualisation of both constructs. This could be due to the unique country specific variables that influence unions, as well as the individual factors that influence a union member's commitment.

The primary aim of this study was to investigate the extent to which union commitment and demographic factors explain union participation. The secondary aim of this study was to assess the portability and psychometric soundness of current measures of union commitment and union participation.

\section{RESEARCH DESIGN}

\section{Research approach}

A relational, cross-sectional design was applied using the survey method. The adoption of quantitative methods and the use of statistical analyses ensured comparability with previous research and provided for the efficient communication of results.

\section{Participants}

A convenience sample of 93 of trade union members was taken from members of a prominent South African trade union. Consisting of 81 males and nine females (three unanswered, $\mathrm{n}$ =93), the participants had been part of the union for between 
one and twenty years (mean $=6.5$ ). The majority of participants were male (87\%), married (61\%) and regarded themselves as Coloured (57\%). The average age of participants was 40.5 (range $=25-79$ years) and organisational tenure ranged from one to 34 years $($ mean $=10.5)$. Few participants had obtained Standard 8 (Grade 10) as their highest level of education, and only three participants had managed to obtain a qualification at a tertiary level.

\section{Measures}

The survey was developed using a number of scales available in the literature. The Bagraim (2005), Sverke and Kuruvilla (1995) and Kelloway, Catano and Southwell (1992) scales were used, but several items were modified to suit the South African audience. The Bagraim (2005) and Sverke and Kuruvilla (1995) scales were utilized to measure union commitment. In particular, Bagraim's (2005) scale was used to measure affective as well as continuance commitment to the union. The Sverke and Kuruvilla (1995) scale, on the other hand, was used to measure instrumental rationality-based commitment. With regard to outcomes of commitment, Kelloway et al.'s (1992) union commitment scale was used as a measure of the participants' willingness to work for the union, as well as their feelings of responsibility to the union. All responses were made on a five-point Likert scale, with responses ranging from one to five [Strongly Disagree (1) to Strongly Agree (5)].

\section{Procedures}

After securing permission from shop stewards in two organisations, three presentations were made to groups of trade union members to explain the nature and scope of the research. Attendees were encouraged to complete the survey questionnaires after each presentation and place them in a sealed box. Some attendees chose to complete the questionnaire later and so submitted their questionnaires into a sealed box that was placed in their shop steward's office. All responses were anonymous and participants were instructed not to write their names on the questionnaire. Established ethics protocols were followed and the research was approved by a university ethics in research committee prior to the commencement of the research.

\section{RESULTS}

\section{Data preparation}

Raw data was entered into a Microsoft Excel spreadsheet and the data cleaned using procedures recommended by Weiss and Townsend (2005). These procedures ensured that out of range data was corrected, and that duplicate and non-response cases were removed. Hardcopy questionnaires were randomly selected, and written responses were checked against their corresponding electronic entries to verify the accuracy of the data entry process.

\section{Scale dimensionality}

Principal-axis common factor analysis was conducted to measure the dimensionality of the Trade union commitment, Participation, Willingness to participate, Responsibility to the union, Intention to quit the union and Organisational commitment scales. Factor inclusion was based on Kaiser's rule (i.e. that each factor has an eigenvalue greater than 1). Items were removed if they cross-loaded across more than one factor, or if the magnitude of their loading on the appropriate factor was less than 0,3 .

Items on the Participation scale were first reduced after considering the inter-item correlation matrix, as the sample size was insufficient to conduct factor analysis on all 18 original items. Subsequently, after a process of stepwise factor analysis, seven items were retained. All the Trade Union
Commitment items (including Affective union commitment and Continuance union commitment) loaded on one factor, as did items in the Willingness to Participate, Responsibility to the union, and Intention to quit the union scales. The items in the Organisational commitment scale loaded on two factors as expected, namely Affective organisational commitment and Continuance organisational commitment. An examination of the Scree plots for each factor analysis confirmed the above determinations.

\section{Scale reliability}

The Cronbach's alpha values of all variables fall within the range of 0,851 and 0,951 . These values are high for social science empirical research but are similar to the reliability coefficients found by Fullagar, Clark, Gallagher and Gordon (1994) where Cronbach alpha's for union commitment and other union-related variables ranged from 0,828 to 0,950 .

\section{Relationship between variables}

On average, participants showed a relatively high level of Participation. Based on a 5-point Likert scale, the average response was 3,886. Similarly, participants displayed high levels of commitment with an average response of 3,711 . Following from this, it is not surprising that Participation and Trade union commitment were highly correlated with one another $(r=0,770, \mathrm{p}<0,0001)$. In addition to this, Participation, Trade union commitment, Willingness to participate and Responsibility to the union all displayed significant correlations with each other.

As expected, Age, Union tenure and Organisational tenure were all strongly correlated with one another. Interestingly, Union tenure was not significantly correlated to Participation or any other variable. Organisational tenure was negatively associated with Trade union commitment $(r=-0,227, \mathrm{p}<0,05)$ and Participation $(r=-0,307, \mathrm{p}<0,01)$. High inter-correlations between variables (generally from 0,7 upwards) signal the danger of multicollinearity (Leahy, n.d.). Multicollinearity occurs when two independent variables are correlated with one another to the point where one scale becomes redundant as it measures almost exactly the same thing as the other scale. This becomes problematic when explaining variance in the dependent variable, because the distinct effects of each independent variable are not easily distinguishable (Leahy, n.d.).

Given that the correlation between Trade union commitment and Willingness to participate $(r=0,694)$ closely approaches the benchmark for multicollinearity, Willingness to participate was removed. Consequently, the effect of our primary independent variable Trade union commitment on Participation can be more clearly observed.

\section{Demographic differences in union participation levels} No differences in Participation were found between married and single participants $(t=-0,859, p=0,393)$. Similarly, and contrary to Metochi's (2002) findings; there were no significant differences between the participation levels of men and women $(t=-0,781, p=0,437)$. It must be noted that the number of men in the sample overwhelmingly outnumbered the number women, which could compromise the veracity of this finding. Levene's test for normality proved to be insignificant $(F=2,784, p=0,987)$ and hence the data normally distributed, albeit based on unrepresentative categories.

Race differences were examined across many variables but the lone white participant in the study was excluded as variance cannot be calculated on a category size of $\mathrm{N}=1$. Our findings revealed no significant differences in Responsibility to the union across race $(t=1,086, p=0,281)$. Blacks were however found to 
TABLE 1

DESCRIPTIVE STATISTICS OF ALL VARIABLES

\begin{tabular}{|c|c|c|c|c|c|c|c|c|c|c|c|c|}
\hline & Mean & SD & 1 & 2 & 3 & 4 & 5 & 6 & 7 & 8 & 9 & 10 \\
\hline 1. Age & 40,482 & 10,241 & & & & & & & & & & \\
\hline 2. Org tenure & 10,270 & 7,824 & $0,418 * * * *$ & & & & & & & & & \\
\hline 3. Union tenure & 6,593 & 4,512 & $0,395 * * * *$ & $0,587 * * * *$ & & & & & & & & \\
\hline 4. Part & 3,886 & 0,820 & $-0,152$ & $-0,307$ * * & 0,022 & $(0,908)$ & & & & & & \\
\hline 5. TU Com & 3,711 & 0,830 & 0,020 & $-0,227$ * & $-0,012$ & $0,770 * * * *$ & $(0,916)$ & & & & & \\
\hline 6. Will & 3,728 & 0,843 & $-0,042$ & $-0,202$ & 0,169 & $0,678 * * * *$ & $0,694 * * * *$ & $(0,868)$ & & & & \\
\hline 7. RespU & 4,150 & 0,583 & $-0,139$ & $-0,180$ & $-0,046$ & $0,537 * * * *$ & $0,474 * * * *$ & 0,349 * * & $(0,851)$ & & & \\
\hline 8. QuitU & 1,744 & 1,007 & 0,216 & $0,304 * *$ & 0,123 & $-0,320 * *$ & $-0,398 * * * *$ & $-0,377 * * *$ & $-0,235^{*}$ & $(0,951)$ & & \\
\hline 9. $A C-O$ & 3,521 & 0,913 & $-0,015$ & 0,001 & 0,101 & $0,387 * * * *$ & $0,394 * * * *$ & 0,209 & 0,292 * * & $-0,089$ & $(0,935)$ & \\
\hline 10. $C C-O$ & 3,286 & 1,106 & $-0,068$ & $-0,024$ & $-0,090$ & 0,020 & 0,150 & $-0,048$ & 0,013 & $-0,037$ & $0,423 * * * *$ & $(0,895)$ \\
\hline
\end{tabular}

Note: Cronbach alphas displayed in brackets along diagonal, ${ }^{* * * *} \mathrm{p}<0,0001,{ }^{* * *} \mathrm{p}<0,001,{ }^{* *} \mathrm{p}<0,01,{ }^{*} \mathrm{p}<0,05 ; \mathrm{n}=78$ after casewise deletion of missing data, Correlations calculated after reductions based on the factor analysis, Legend: $T U \mathrm{Com}=$ Trade union commitment, Will $=$ Willingness to participate, RespU $=$ Responsibility to the union, QuitU $=$ Intention to quit the union, OC Organisational commitment

be more willing to participate in union-related activities than their Coloured counterparts were $(t=-4,139, p<0,0001)$. Similarly, they were found to display more union commitment $(t=-3,589, p<0,001)$ and higher levels of participation $(t=-$ $3,552, \mathrm{p}<0,001)$. In all cases, Levene's Test for Equality of Variances was performed; and in all cases the result was not significant.

An ANOVA analysis showed that no significant differences in Participation are attributable to the differences in the education level of participants $(F=0,958, p=0,387)$. Only one participant had a degree, while two had a diploma. For the purpose of robust results these two categories were excluded from the analysis. As a result, the ANOVA analysis was used to assess the difference in Participation between participants who had lower than a Std 8 certificate, a Std 8 certificate or a matric certificate.

Explaining union participation

Participation was modelled on Trade union commitment in a simple regression model. As expected, the variable explained a significant $56 \%$ of the variance in Participation $\left(R^{2}=0,56\right.$, $p<0,0001)$.

TABLE 2

SIMPLE REGRESSION ANALYSIS: DV $=$ PARTICIPATION

\begin{tabular}{lcccccc}
\hline Variable & Beta & SE of Beta & B & SE of B & $\mathbf{t}(90)$ & p-level \\
\hline $\begin{array}{l}\text { Trade union } \\
\text { commitment }\end{array}$ & 0,747 & 0,070 & 0,736 & 0,069 & 10,672 & $*$ \\
\hline
\end{tabular}

Note: $\mathrm{R}=, 747 ; \mathrm{R}^{2}=, 559 ;$ Adjusted $\mathrm{R}^{2}=, 553 ; \mathrm{F}(1,90)=113,89 ; \mathrm{p}<, 0001 ; \mathrm{SE}$ of estimate: $0,548,{ }^{*} \mathrm{p}<0,0001$

To explain more of the variance in Participation, Responsibility to the union was added to the simple regression with Trade union commitment. The inclusion of Responsibility to the union made a significant increase to the proportion of explained variance (beta $=0,209, p<0,01$ ) which rose to nearly $60 \%\left(R^{2}=0,595, p<0,0001\right)$. Both independent variables were significant in the regression model ( beta $_{\text {Responsibility to the union }}=0,209, p<0,01 ;$ beta $_{\text {Trade union commitment }}$ $=64,732, p<0,0001)$.

Hierarchical regression was conducted to examine how much variance in Participation is explained by Trade union commitment, after controlling for demographic variables. In step one of the hierarchical regression, all of the demographic variables (Gender, Marital status, Race, Education, Age, Organisation tenure and Union tenure) were included as control variables. The overall fit was significant $\left(R^{2}=0,263, p<0,01\right)$, and indicated that $26 \%$ of the variance in Participation is explained by demographic factors. The partial regression coefficients of only three out of the seven variables were statistically significant, namely Organisation tenure (beta $=-0,457, p=0,001$ ), Union tenure (beta $=0,327, \mathrm{p}<0,05)$ and Race (beta $=-0,232$, $\mathrm{p}=0,034)$.

TABLE 3

MULTIPLE REGRESSION ANALYSIS: DV = PARTICIPATION

\begin{tabular}{lcccccc}
\hline Variable & Beta & SE of Beta & B & SE of B & $\mathbf{t}(88)$ & p-level \\
\hline $\begin{array}{l}\text { Trade union } \\
\text { commitment }\end{array}$ & 0,647 & 0,078 & 0,634 & 0,076 & 80,335 & $*$ \\
$\begin{array}{l}\text { Responsibility } \\
\text { to the union }\end{array}$ & 0,209 & 0,078 & 0,294 & 0,109 & 20,696 & 0,008 \\
\hline
\end{tabular}

Note: $\mathrm{N}=91 ; \mathrm{R}=, 771 ; \mathrm{R}^{2}=, 595 ;$ Adjusted $\mathrm{R}^{2}=, 585 ; \mathrm{F}(2,88)=64,549 ; \mathrm{p}<0,0001$ SE of estimate: $0,527,{ }^{*} \mathrm{p}<, 0001$

Trade union commitment was added to the regression model in step two, and explained a further $43 \%$ of the variance in Participation $\left(\Delta R^{2}=0,427, p<0,0001\right)$. As expected, the overall fit was significant $\left(R^{2}=0,690, p<0,0001\right)$, however none of the demographic variables made a significant contribution to explained variance in the final regression model. 
TABLE 4

HiERARCHICAL REgRESSION ANALYSIS: DV = PARTICIPATION

\begin{tabular}{lcccccc}
\hline Variable & Beta & SE of Beta & B & SE of B & t(65) & p \\
\hline Step 1 & & & & & & \\
Gender & 0,103 & 0,074 & 0,271 & 0,193 & 1,405 & 0,165 \\
Marital Status & 0,014 & 0,073 & 0,024 & 0,127 & 0,192 & 0,848 \\
Race & 0,015 & 0,075 & 0,019 & 0,089 & 0,212 & 0,832 \\
Education & 0,009 & 0,075 & 0,009 & 0,069 & 0,127 & 0,899 \\
Age & $-0,150$ & 0,080 & $-0,012$ & 0,006 & $-1,877$ & 0,065 \\
Organisation tenure & $-0,198$ & 0,093 & $-0,022$ & 0,010 & $-2,130$ & 0,037 \\
Union tenure & 0,206 & 0,089 & 0,040 & 0,017 & 2,328 & 0,023 \\
Step 2 & & & & & & \\
$\begin{array}{l}\text { Trade union } \\
\text { commitment }\end{array}$ & 0,745 & 0,079 & 0,713 & 0,075 & 9,463 & $*$ \\
\hline
\end{tabular}

Notes: $\mathrm{N}=74$, After step 1: $\mathrm{R} 2=0,267$; After step 2: $\mathrm{R} 2=0,690 \Delta \mathrm{R} 2=0,427, \mathrm{~F}(8,65)=$

$18,074, \mathrm{p}<0,0001$, SE of estimate $=0,484,{ }^{*} \mathrm{p}<0,0001$

\section{DISCUSSION}

Three sets of results deserve further explication. These include (a) the dimensionality of the key variables (Trade union commitment and Participation in the trade union), (b) the relationship between these two variables, and (c) differences in participation across demographic groups. Each will be discussed below.

Since the pioneering work of Gordon et al. (1980), there have been almost as many proposed dimensions of trade union commitment as there are studies examining it (Bamberger, Kluger and Suchard, 1999). Van den Veen and Klandermans (1995) noted that this was especially true when comparing union commitment research across countries. This study found both trade union commitment and participation in the trade union to be unidimensional constructs. The unidimensionality of participation may be explained by constrained opportunities for union participation; either a result of inaccessible shop stewards (Barclay \& Thacker, 2001), insufficient leadership within the union (Kelloway \& Barling, 1993) or because small and medium-sized companies provide little scope for a wide variety of union-related activities.

Due to the cross-sectional design of this study, we cannot infer a causal relationship between the trade union commitment and participation. Nevertheless, there is clear evidence from this study and from previous research that union commitment is an antecedent and primary predictor of union participation (Chan, Snape \& Redman, 2004); in a relationship that is consistent and positive (Fullagar \& Barling, 1989). The few longitudinal studies that have been conducted have consistently found that union commitment helps predict union participation (Fullagar, Gallagher, Clark \& Carroll, 2004; Fullagar, Gallagher, Gordon \& Clark, 1995).

The high average levels of Trade union commitment and Participation found in this study could reflect the amicable industrial relations context in which participants worked. There were no signs of hostility between the union and management. The amicable industrial relations context may also explain the significant negative relationship between Organisational tenure and both Participation and Trade union commitment. This finding implies that the longer participants remain with the company, the less likely they are to participate in the union, a finding consistent with that of Snape and Chan (2000). The high level of Trade union commitment expressed by participants in this study may also have been influenced by the nation-wide strikes that were in progress within the aviation, mining, and retail industries during the data collection phase of this study. Periods of industrial action are likely to heighten awareness of union membership amongst union members, leading members to express greater solidarity with their union and commitment to the union, especially when it is a member of the same union federation as the trade unions undertaking industrial action.

Gordon et al. (1980) found union commitment to be normally distributed amongst trade union members regardless of demographics. Fullagar (1986) found differences in responsibility to the trade union between Black and White trade union members but attributed this to differences in organisational tenure. In this study, there were substantially more Coloured than Black participants and no information was available on the representativeness of the sample. Therefore, the higher levels of trade union commitment and participation amongst Black participants in this study should not be overinterpreted. Nevertheless, the difference may be attributable to different needs to obtain recognition within the union, greater feelings of isolation, different past 'work experiences' which create different levels of commitment to trade unionism, and greater identification with the political ideology of the trade union. All of these attributions are speculative and beg further research.

\section{RECOMMENDATIONS}

Future studies with larger samples and longitudinal research designs would strengthen claims regarding the validity, generalisability and reliability of the research findings (Sinclair $\&$ Tetrick, 1995). Future studies that refined Friedman and Harvey's (1986) behavioural intentions construct as a composite of willingness to participate and responsibility to the union may help address the redundancy evidenced by the high correlation between these two variables. As indicated by Chacko's (1985) research on union commitment, understanding behavioural intentions may be important for improving levels of union participation. There is large scope for investigating the effect of leadership within South African trade unions. It is probable that a particular leadership style (of union officials, shop stewards) can influence the levels of participation in unions. Union leaders and shop stewards would benefit from knowing which leadership styles encourage higher levels of participation.

Context effects should be clearly specified in future research. South Africa has experienced a re-emergence of allegedly disruptive and violent behaviour during strikes (Cook, 2005; "Cape Town police ...", 2005). Since the industrial climate seemingly impacts on trade union participation, examining union commitment and participation in times of a more peaceful industrial relations climate may render different results from those found in this study. Similarly, cultural factors may be a significant factor in motivating union participation (Snape \& Chan, 2000). Despite the high visibility of COSATU and its strategic partnership with the ruling party, tension between the trade union movement and the government has increased because of a divergence between their macroeconomic goals and priorities (Innes, 1997). Measuring union participation across different socio-politicoeconomic environments and trade union groupings may provide different and interesting results.

\section{CONCLUSION}

This study adds to the limited body of knowledge that exists on trade union commitment and participation within the South African context. It has been shown across nations, cultures and sectors that the relationship between trade union commitment and union participation is strong and stable. The results of this study indicate that even after controlling for demographic 
variables, $43 \%$ of the variance in union participation can be explained by union commitment. In the midst of global decline in union membership, knowing how to encourage trade union participation is of great value to union leaders. Future research should seek to assess the generalisability of these findings and attempt to determine the drivers of trade union commitment.

\section{REFERENCES}

Bagraim, J.J. (2005). Measuring union commitment in South Africa. Unpublished manuscript. School of Management Studies. University of Cape Town.

Bamberger, P.A., Kluger, A.N., Abraham, N., \& Suchard, R. (1999). The antecedents and outcomes of union commitment: A meta-analysis. Academy of Management Journal, 42), 304-318.

Barling, J., \& Fullagar, C. (1991). Predictors and outcomes of different patterns of organizational and union loyalty. Journal of Occupational Psychology, 64, 129-143.

Barling, J., Fullagar, C., \& Kelloway, E.K. (1992). The union and its members: A psychological approach. New York: Oxford University Press.

Bendix, S. (2004). Industrial Relations in South Africa (4th ed.). Cape Town: Juta.

Cape Town police arrest striking shop workers. (2005, July 22). Cape Argus. Retrieved September 12, 2005 from http://www.iol.co.za/index/php?_id=13.

Chacko, T.I. (1985). Member participation in union activities: Perceptions of union priorities, performance, and satisfaction. Journal of Labor Research, 6, 363-373.

Cook, B. (2005). Messy Medunsa. Retrieved, September 12, 2005 from http://www.carteblanche.co.za/display/dispaly. asp? $\mathrm{id}=2815$.

Clawson, D., \& Clawson, M. (1999). What has happened to the US labor movement? Union decline and renewal. Annual Reviews, 25, 95-119.

Deery, S.J., \& Iverson, R.D. (1998). Antecedents and consequences of dual and unilateral commitment: A longitudinal study. Department of Management Working Paper in Human Resource Management and Industrial Relations, University of Melbourne, No. 1.

Durrheim, K. (2002). Research design. In M. Terre Blanche \& K. Durrheim, Research in practice: Applied methods for the social sciences. UCT Press: Cape Town

Fairbrother, S. (2000). British trade unions facing the future. Capital and Class, 71, retrieved March 4, 2005, from EbscoHost database.

Friedman, L., \& Harvey, R.J. (1986). Factors of union commitment: The case for a lower dimensionality. Journal of Applied Psychology, 71, 371-376.

Fullagar, C. (1986). A factor analytic study on the validity of a union commitment scale. Journal of Applied Psychology, 71, 129-136.

Fullagar, C., \& Barling, J. (1989). A longitudinal test of a model of the antecedents and consequences of union loyalty. Journal of Applied Psychology, 74, 213-227.

Fullagar, C., Clark, P.F., Gallagher, D.G., and Gordon, M. E. (1994). A model of the antecedents of early union commitment: the role of socialization experiences and steward characteristics. The Journal of Organizational Behavior, 15, 517 - 533.

Fullagar, C., Gallagher, D.G., Clark, P.F., \& Carroll, A.E. (2004). Union commitment and participation: A ten-year longitudinal study. Journal of Applied Psychology, 89, 730-737.

Fullagar, C., Gallagher, D.G., \& Gordon, M.E., \& Clark, P.F. (1995). Socialization on union commitment and participation: A longitudinal study. Journal of Applied Psychology, 89, 147-157.

Fullagar, C., McCoy, D., \& Shull, C. (1992). The socialization of union loyalty. Journal of Organizational Behavior, 13, 13-26.

Gallagher, D.G., \& Clark, P.F. (1989). Research on union commitment: Implications for labor. Labor Studies Journal, 14 (1), 52-71.

Gordon, M.E., Philpot, J.W., Burt, R.E., Thompson, C.A., \& Spiller, W.E. (1980). Commitment to the union: Development of a measure and an examination of its correlates. Journal of Applied Psychology, 65, 479-499.

Heshizer, B., \& Lund, J. (1997). Union commitment types and union activist involvement: Lessons for union organizers and labor educators. Labor Studies Journal, 22 (2), 66-83.

Innes, D. (1996). Organized labour and the macro-economic strategy. Labour Brief, 8 (3), 7- 16.

Janse Van Rensberg, K., \& Roodt, G. (2005). The perceptions of employment equity and black economic empowerment as predictors of union commitment. SA Journal of Industrial Psychology, 31, 55-64.

Johnson, W.R., \& Johnson, G.J. (1996). A model of union participation among US blue-collar workers. Journal of Psychology, 13, 661-667.

Leahy, K. (n.d.). Multicollinearity: When the solution is the problem. Retrieved September 25, 2005, from http://www.dmreview.com/whitepaper/WID427.pdf

McLean Parks, J., Gallagher, D.G., \& Fullagar, C.J.A. (1995). Operationalizing the outcomes of union commitment: The dimensionality of participation. Journal of Organizational Behavior, 16 (Special Issue), 533-555.

Metochi, M. (2002). The influence of leadership and member attitudes in understanding the nature of union participation. British Journal of Industrial Relations, 40 (1), 87-111.

McShane, S. (1986). The multidimensionality of union participation. Journal of Occupational Psychology, 59, 177-187.

Rosnow, R.L., \& Rosenthal, R. (2004). Beginning behavioral research: A conceptual primer (5 $5^{\text {th }}$ ed.). Englewood Cliffs, NJ. Pearson Prentice Hall.

Sinclair, R.R., \& Tetrick, L.E. (1995) Social exchange and union commitment: A comparison of union instrumentality and union support perceptions. Journal of Organizational Behavior, 16, 669-680.

Smith, P., \& Morton, G. (1993). Union exclusion and the decollectivisation of industrial relations in contemporary Britain. British Journal of Industrial Relations, 31 (1), 97-114.

Snape, E., Redman, T., \& Chan, A.W. (2000). Commitment to the union: A survey of research and the implications for industrial relations and trade unions. International Journal of Management Review, 2 (3), 205-230.

Snape, E., \& Chan, A.W. (2000). Commitment to company and union: Evidence from Hong Kong. Industrial Relations, 39, 445-459.

Sverke, M., \& Kuruvilla, S. (1995). A new conceptualization of union commitment. Journal of Organizational Behavior, 16 (Special Issue: Union Commitment), 505-532.

Tetrick, L.E. (1995). Developing and maintaining union commitment: A theoretical framework. Journal of Organizational Behavior, 16 (Special Issue: Union Commitment), 583-595.

Theron, J. (2003). Employment is not what it used to be. Industrial Law Journal, 24, 1247-1282.

Van den Veen, G., \& Klandermans, B. (1995) Introduction. Journal of Organizational Behaviour, 16 (Special Issue: Union Commitment), 503-504.

Weiss, J., \& Townsend, R.J. (2005). Leading Edge: Using Excel to clean and prepare data for analysis. TIP: The IndustrialOrganizational Psychologist, 4 (3), 89- 96. 